European Journal of Phycology

August 2015, Volume 50, Issue 4, Pages 371-383

http://dx.doi.org/10.1080/09670262.2015.1063698

http://archimer.ifremer.fr/doc/00280/39089/

(C) 2015 British Phycological Society

\title{
Environmental factors affecting maerl bed structure in Brittany (France)
}

\author{
Dutertre Mickael ${ }^{1,{ }^{*}}$, Grall Jacques $^{2}$, Ehrhold Axel $^{3}$, Hamon Dominique $^{1}$
}

${ }^{1}$ IFREMER, ODE/DYNECO/Laboratoire Écologie Benthique, Technopôle Brest-Iroise, B.P. 70, 29280

Plouzané, France

2 Institut Universitaire Européen de la Mer, UMS 3113, Observatoire Domaine Côtier, 29280 Plouzané, France

${ }^{3}$ IFREMER, REM/GM/Laboratoire Environnements Sédimentaires, Technopôle Brest-Iroise, B.P. 70, 29280 Plouzané, France

* Corresponding author : Mickael Dutertre, email address : mickael.dutertre@yahoo.fr

\begin{abstract}
:
This study used a large spatial scale approach in order to better quantify the relationships between maerl bed structure and a selection of potentially forcing physical factors. Data on maerl bed structure and morpho-sedimentary characteristics were obtained from recent oceanographic surveys using underwater video recording and grab sampling. Considering the difficulties in carrying out real-time monitoring of highly variable hydrodynamic and physicochemical factors, these were generated by three-dimensional numerical models with high spatial and temporal resolution. The BIOENV procedure indicated that variation in the percentage cover of thalli can best be explained (correlation $=0.76$ ) by a combination of annual mean salinity, annual mean nitrate concentration and annual mean current velocity, while the variation in the proportion of living thalli can best be explained (correlation $=0.47$ ) by a combination of depth and mud content. Linear relationships showed that the percentage cover of maerl thalli was positively correlated with nitrate concentration $(R 2=0.78, P<0.01)$ and negatively correlated with salinity $(R 2=0.81, P<0.01)$, suggesting a strong effect of estuarine discharge on maerl bed structure, and also negatively correlated with current velocity $(R 2=0.81, P<0.01)$. When maerl beds were deeper than $10 \mathrm{~m}$, the proportion of living thalli was always below $30 \%$ but when they were shallower than $10 \mathrm{~m}$, it varied between 4 and $100 \%$, and was negatively correlated with mud content $(R 2=0.53, P<0.01)$. On the other hand, when mud content was below $10 \%$, the proportion of living thalli showed a negative correlation with depth $(R 2=0.84, P<0.01)$. This large spatial scale explanation of maerl bed heterogeneity provides a realistic physical characterization of these ecologically interesting benthic habitats and usable findings for their conservation and management.
\end{abstract}

Keywords : Benthic habitats, Brittany, environmental factors, estuary, large spatial scale, maerl 


\section{Introduction}

Maerl beds refer to intricate benthic habitats constituted by accumulations of living and dead unattached thalli of coralline algae which occur in tropical, temperate and polar environments (Bosence, 1983; Freiwald \& Henrich, 1994). In European waters, most of them are patchily distributed and found at less than $30 \mathrm{~m}$ deep, except in the Mediterranean Sea where they can be found down to $100 \mathrm{~m}$ (Jacquotte, 1962; Birkett et al., 1998; Hall-Spencer, 1998; De Grave et al., 2000; Foster, 2001). Although this geographical distribution seems to be mainly constrained by the ecological requirements of the species constituting European maerl beds, such as Phymatolithon calcareum (Pallas) W.H. Adey \& D.L. McKibbin and Lithothamniom corallioides (P.L. Crouan \& H.M. Crouan) P.L. Crouan \& H.M. Crouan, only a few studies have investigated the relationships between environment and physiological responses in these species, resulting in very variable conclusions about their ecological niches (Adey \& McKibbin, 1970; Hall-Spencer \& Moore, 2000; Wilson et al., 2004; Martin et al., 2006; 2007a; 2007b). Furthermore, although the morpho sedimentary environment of maerl beds can be clearly established by field samplings, the effect of the highly-variable hydrodynamics and physico-chemical properties of the water column may be misinterpreted due to the difficulty of carrying 
out real-time monitoring, especially in temperate coastal ecosystems subject to a semi-diurnal tidal cycle, freshwater outflows and a seasonal cycle (Barbera et al., 2003; Wilson et al., 2004; Dutertre et al., 2013). The development of threedimensional environmental models generating continuous data on the variability of a large variety of environmental factors, including hydrodynamic conditions and physico-chemical properties (Cugier \& Le Hir, 2002; Ménesguen et al., 2007), can therefore greatly improve the identification of environmental factors responsible for the existence, structure and spatial distribution of benthic habitats such as maerl beds (Warwick \& Uncles, 1980; Gogina \& Zettler, 2010; Dutertre et al., 2013).

Accumulations of calcified thalli result in a large number of microhabitats (microniches) formed by the space between branched forms together with hard calcareous surfaces. Such complexity is characterized by a high diversity and density of macrofaunal and algal species (Birkett et al., 1998; Barbera et al., 2003; Steller et al., 2003; Grall et al., 2006; Hall-Spencer et al., 2008; Peña \& Bárbara, 2008; 2010; Dutertre et al., 2013). Maerl beds also provide nursery grounds of importance for commercial species of fish and shellfish (Hall-Spencer et al., 2003; Steller et al., 2003). Being hot-spots of biodiversity and considered as a non-renewable resource due to the slow growth rate of the thalli (Wilson et al., 2004), maerl beds are a priority of the European conservation policies, in particular when being massively extracted to provide calcareous products for soil conditioning, water filtration systems, cosmetics and also for the oil industry (Barbera et al., 2003). The species richness and density of the associated biodiversity are strongly dependent on the threedimensional structure of the maerl beds corresponding to the density and morphology of thalli, the heterogeneity of the constituent particles (coexistence of fine particles with large maerl thalli), and on the proportion of living thalli (Steller et al., 2003; 
Sciberras et al., 2009; Meihoub Berlandi et al., 2012). In spite of the ecological influence of the structural heterogeneity of maerl beds, few data are available about its determinism and evolution. Thus, although water motion, sedimentation and some human activities have been considered driving factors of the variations in morphology and vitality of maerl (Scoffin et al., 1985; Steller \& Foster, 1995; Marrack, 1999; Barbera et al., 2003), no clear quantitative relationships have been established between environmental factors and maerl bed structure. In order to understand better how the structure of maerl beds differs between them and how it may change with time, a clear quantification of the influence of environmental factors forcing maerl bed structure now appears necessary (Barbera et al., 2003; Grall \& Hall-Spencer, 2003; Przeslawski et al., 2011). Such quantification, essential for the development of management tools such as habitat modelling, can be accomplished by a large spatial scale approach, enabling the elimination of local misinterpretations by comparing distant sites and, therefore, a more realistic physical characterization of benthic habitats, as well as a discrimination between human and natural effects (Ellis \& Schneider, 2008; Dutertre et al., 2013).

The aim of this study was to investigate and quantify relationships between variations in maerl bed structure and a selection of potentially-forcing physical factors in order to provide a consistent baseline for conservation and management purposes. This was performed by integrating local structural data regarding the maerl beds of Brittany, which are some of the most extensive in Europe, into a large spatial scale approach. Maerl bed structure was described from data on the percent cover of maerl thalli and the proportion of living thalli which were recently obtained using a combination of underwater video-recordings and grab samplings. Quantitative relationships between maerl bed structure and environmental factors were 
determined using hydrodynamic and physico-chemical variables generated by threedimensional numerical models in order to better integrate their high spatio-temporal variability.

\section{Materials and methods}

\section{Remote sensing and sampling strategy}

Within the framework of the French program REBENT ("Réseau Benthique") and the European Water Framework Directive, the physical structure of five maerl beds of the Brittany coast was investigated by IFREMER (French Research Institute for Exploration of the Sea) using a combination of remote sensing systems, underwater video-recordings and grab samplings. The maerl beds of Paimpol and Molène were investigated in 2008, while those of Glénan, Trévignon and Belle-lle were investigated in 2009 (Figure 1). A digital sidescan sonar EDGETECH DF$1000^{\odot}$, towed by the coastal vessel THALIA, was first used to carry out acoustic profiles in order to identify maerl beds amongst the other morpho-sedimentary units, while geographic locations were determined by a differential Global Positioning System THALES AQUARIUS ${ }^{\odot}$. Sediment samplings and underwater videorecordings were then performed within the areas where maerl beds had been identified on acoustic profiles (Table 1). Sediment samples were collected with a $0.042 \mathrm{~m}^{2}$ Shipek grab deployed from the coastal vessel THALIA, put into plastic bags and frozen during their storage. In the laboratory, about $300 \mathrm{~g}$ of each sediment sample was first wet-sieved using a $50-\mu \mathrm{m}$ stainless steel sieve. The fraction above 
$50 \mu \mathrm{m}$ was dry-sieved on a sieve shaker, using a range of stainless steel sieves placed at -4 phi intervals, down to 4 phi $(63 \mu \mathrm{m})$. The retained fractions were weighed in order to give a full particle size distribution and GRADISTAT 4.0 software was used to calculate the mud content of the distribution, which corresponds to the percentage of particles smaller than $63 \mu \mathrm{m}$. Living and dead maerl thalli were included in sedimentary analysis. Underwater video-recordings were made using a KONSBERG OE1372A-003 high-resolution colour video camera, equipped with a waterproof projector and mounted on a metallic support in order to have a constant distance between the camera and the surface of the maerl bed. The video camera was towed by the coastal vessel THALIA above the maerl beds and dropped down randomly near sediment sampling sites in order to obtain ten $0.160 \mathrm{~m}^{2}$ photoquadrats of the bottom.

In 2010, the European Institute for Marine Studies (IUEM) investigated the physical structure of the maerl beds of Rade de Brest and Camaret (Figure 1). Within each maerl bed, random sediment samplings were performed with a $0.100 \mathrm{~m}^{2}$ Smith McIntyre grab and then processed using the method described above (Table 1). However, these investigations did not include underwater video-recordings.

Analysis of the physical structure of the maerl beds

The physical structure of the maerl beds was characterized by the percent cover of maerl thalli (live + dead) determined in situ and the proportion of living thalli determined in the laboratory. The percent cover of maerl thalli (live + dead) was estimated by superimposing a $20 \times 20 \mathrm{~cm}$ square grid on drop-down still images of the 
maerl beds in order to determine the percentage of the seabed covered by maerl. Due to the difficulty of distinguishing between living and dead thalli in the field, the proportion of living thalli was estimated in the laboratory from the grab samples used for the sedimentary analysis. According to their marked coloration, varying from reddish-pink to reddish-purple, all the living thalli sampled in grab were separated from the rest of the sediment (including dead thalli) and deposited on a $10 \times 10$ square grid corresponding to the area of seabed sampled by the grab $\left(0.042 \mathrm{~m}^{2}\right.$ and 0.100 $\mathrm{m}^{2}$ for the Shipek and Smith Mclntyre grab samples, respectively) in order to determine the proportion of living thalli (i.e. the number of the sub-squares filled by living thalli on the grid) on the seabed. Except for the subarea R16 of the maerl bed of Rade de Brest where the seabed was $100 \%$ covered by maerl stacks, the amount of living thalli has never exceeded the size of the grid used to determine the proportion of living thalli. While the proportion of living thalli was determined for each sampling station of the seven maerl beds (Belle-lle, Trévignon, Glénan, Camaret, Rade de Brest, Molène and Paimpol), the percent cover of maerl thalli was not determined for the maerl beds of Rade de Brest and Camaret due to the lack of dropdown still images. $P$. calcareum and $L$. corallioides have been reported as the dominant maerl-forming species in Brittany (Grall \& Hall-Spencer, 2003), however, as visual inspection of the thalli cannot enable a reliable taxonomic identification of the maerl species, thalli were considered as if they belonged to the same maerl species. Nevertheless, visual inspection enables a qualitative description of the relative thallus morphology taking into account the shape and the branching pattern. 
model has been developed by IFREMER to provide realistic descriptions of spatial and temporal variations in coastal hydrodynamics (Ménesguen et al., 2007; 2014; Lazure \& Dumas, 2008). It uses regular orthogonal grids with square meshes, aligned with geographic axes, in the horizontal plane. For each mesh, the water column is divided into ten horizontal layers for which thickness is proportional to the local water depth ( $\sigma$-coordinates). Mechanical forcing of the MARS 3D hydrodynamical model is made by barotropic sea-level oscillation at the oceanic boundaries, and wind and atmospheric pressure at the sea surface (Arpege Model, Météo-France). The salinity and temperature are calculated with a classic time integration scheme. Flow rates of rivers such as Loire and Vilaine derive from measured daily discharges. The ECOMARS 3D model, resulting from the coupling of the MARS 3D model and a biochemical model, enables the description of spatial and temporal variations in nutrient (nitrate, phosphate and silicate) concentrations and oxygen saturation. River nutrient concentrations are computed from empirical statistical relationships involving flow rate and time fitted. Suspended particulate matter derives from satellite data and the suspended matter brought by the rivers, which is simply simulated as a particulate conservative tracer. Oxygen saturation derives from oxygen concentration measured in surface and bottom waters by buoys. Environmental simulations generated by MARS 3D and ECOMARS 3D models have been validated by numerous data from monitoring networks for the French coastal zone (e.g. REPHY, MAREL, SOMLIT) and oceanographic cruises. Following the recent development of the models in the framework of the PREVIMER project and the possibility of having good validations by means of satellite observations and seawater measurements, the year 2009 was chosen as the "reference" year to 
generate hydrological variations because of the absence of exceptional climatic events. For the maerl beds of Paimpol, Molène, Glénan, Trévignon and Belle-lle, temperature $\left({ }^{\circ} \mathrm{C}\right)$, salinity, oxygen saturation (\%), suspended particulate matter (SPM, mg. $\mathrm{L}^{-1}$ ) and nutrients concentrations (nitrate and phosphate, $\mu \mathrm{M}$ ) were derived from the ECOMARS 3D-BRETAGNE model (resolution grid $=3 \mathrm{~km}$, period $=$ $12 \mathrm{~h}$ ), while current velocity $\left(\mathrm{m}_{\mathrm{s}} \mathrm{s}^{-1}\right)$ was obtained from the MARS 3D-MANGA (MANche-GAscogne) model (resolution grid $=3 \mathrm{~km}$, period $=1 \mathrm{~h}$ ). For the maerl beds of Rade de Brest and Camaret, the physico-chemical properties of the water column were derived from the ECOMARS 3D-BRETAGNE zoom FINIS model (resolution grid $=500 \mathrm{~m}$, period $=12 \mathrm{~h}$ ), while current velocity $\left(\mathrm{m} \cdot \mathrm{s}^{-1}\right)$ was obtained from the MARS 3D-MANGA model zoom IROISE (resolution grid $=150 \mathrm{~m}$, period $=1$ h).

In its operational configuration, the WAVEWATCH III model is a wind-wave model using unstructured grids with adaptive time stepping, which has been adapted to be interfaced with ocean and atmospheric circulation models (Tolman, 2002; Ardhuin et al., 2014). Wave simulations have been extracted on regular grids for the year 2009 and validated by numerous data from buoys, satellite observations and oceanographic cruises. For all the maerl beds, significant wave agitation $\left(\mathrm{m} \cdot \mathrm{s}^{-1}\right)$ was derived from the WAVEWATCH III ® NORGAS-UG (Nord-Gascogne-Unstructured Grid) model (resolution grid $=200 \mathrm{~m}$, period $=3 \mathrm{~h}$ ).

Temporal and spatial variations in hydrological factors (temperature, salinity, oxygen saturation, SPM concentration, nitrate concentration, current velocity and significant wave agitation) were generated over all the year 2009 using the MARS 3D and WAVEWATCH III environmental models in their operational configurations implemented within the framework of the PREVIMER project (Dumas et al., 2014). 
247 For each hydrological factor, annual descriptive statistics (mean, standard deviation, 248 maximum and minimum) were calculated from the continuous temporal data 249 generated at the horizontal bottom layer of the water column, representing $1 / 10^{\text {th }}$ of 250 the local water depth, in each mesh of the resolution grid covering a part of the maerl beds. Annual standard deviation was used as an indicator of environmental variability.

Statistical analysis

Seabed areas covered by the maerl beds of Paimpol, Molène, Glénan, Trévignon and Belle-lle, were virtually subdivided into geographical subareas according to the $3 \times 3 \mathrm{~km}$ meshes of the resolution grid of the MARS 3D model (Table 1). For these maerl beds, the percent cover of maerl thalli, proportion of living thalli, depth, mud content and wave agitation were therefore averaged within each subarea corresponding to a MARS 3D model's mesh. For the maerl beds of Rade de Brest and Camaret, each subarea corresponded to a single sampling station and to a single $0.5 \times 0.5$ MARS 3D model's mesh (Table 1 ).

The BIOENV procedure, implemented in the PRIMER ${ }^{\odot}$ V6 software package, was used to identify which combination of the tested environmental variables (mud content, depth and the annual descriptive statistics of the hydrological factors generated by the numerical models) best explained variations in maerl bed structure (Clarke \& Ainsworth, 1993). The results of the BIOENV procedure were illustrated by a parallel display of nonmetric multidimensional scaling (NMDS) ordinations of the subareas based on each structural component (percent cover of maerl thalli and proportion of living thalli) of the maerl beds (Bray-Curtis dissimilarities) and the 
272 associated best subset of explanatory environmental variables (Euclidean 273 dissimilarities). Non-parametric Spearman tests, implemented in Sigmastat 3.1 274 software, were also used to determine correlations between environmental 275 predictors. Finally, after checking the normality and homoscedasticity of the 276 distributions, linear regressions were used to describe the relationships between 277 maerl bed structure and selected environmental variables.

278

279

280

281

282

283

284

285

\section{Results}

Structural description of the maerl beds

The total areas of the Brittany maerl beds, which were then virtually subdivided into subareas according to the resolution grids of the MARS 3D model, varied between 1.9 and $23.0 \mathrm{~km}^{2}$ (Table 1).

The maerl bed of Belle-lle corresponded to a single subarea $(B)$ where the seabed was $92.5 \pm 14.5 \%$ covered by maerl thalli, while the proportion of living thalli was $23.4 \pm 15.5 \%$. Most of the thalli were characterized by short branches, while few of them exhibited spherical shapes (Figure 2). Underwater video-recordings showed that living thalli were mainly concentrated in hollows of megaripples generated by wave action.

The maerl bed of Trévignon was subdivided into two subareas (T1 and T2). Within T1, the percent cover of maerl thalli was $73.8 \pm 11.3 \%$, while the proportion of living thalli was $38.3 \pm 13.0 \%$. Within $\mathrm{T} 2$, the seabed was $96.9 \pm 18.3 \%$ covered by maerl thalli, while the proportion of living thalli was $83.0 \pm 16.4 \%$. Thalli were 
characterized by short branches within T1 (Figure 3), while they exhibited more ramified morphotypes with longer branches within T2 (Figure 4).

The maerl bed of Glénan was subdivided into two subareas (G1 and G2). The percent cover of maerl thalli was $78.5 \pm 10.6 \%$ within G1 and $68.5 \pm 23.3 \%$ within G2. Grab samplings showed $10.0 \pm 8.4 \%$ of living thalli within $\mathrm{G} 1$ and $16.5 \pm 10.6 \%$ of living thalli within G2. Within G1 and G2, thalli were relatively small and poorly ramified (Figures 5-6).

The maerl bed of Molène was subdivided into two subareas (M1 and M2). Within M1, the seabed was $71.0 \pm 34.4 \%$ covered by maerl thalli, while the proportion of living thalli was $80.5 \pm 27.5 \%$. Within M2, the seabed was $66.8 \pm 7.2 \%$ covered by thalli, while the proportion of living thalli was $21.6 \pm 16.9 \%$. Ramified thalli were observed within each subarea of the maerl bed of Molène; however, within M2, they were associated with sub-discoidal morphotypes with warty protuberances (Figures 7-8).

The maerl bed of Paimpol was subdivided into three subareas (P1, P2 and P3). The covering of the seabed by thalli within $\mathrm{P} 1, \mathrm{P} 2$ and $\mathrm{P} 3$ was $39.3 \pm 15.7 \%, 42.2 \pm$ $28.6 \%$ and $59.1 \pm 29.6 \%$, respectively. The proportion of living thalli within P1, P2 and P3 was $28.6 \pm 9.5 \%, 24.4 \pm 18.4 \%$ and $37.5 \pm 26.2 \%$, respectively. Highly abraded sub-spheroidal thalli with warty protuberances were the dominant morphotype within P1 (Figure 9), while they were mixed with nodulus and branched ones within P2 (Figure 10). Within P3, branched thalli were clearly dominant (Figure 11).

For the maerl beds of Rade de Brest and Camaret, each sampling station corresponded to a single subarea. On the whole, the proportion of living thalli varied between $16.0 \pm 12.4$ and $100.0 \pm 0 \%$ within the maerl beds of Rade de Brest, while it 
varied between $0.8 \pm 0.2$ and $28.3 \pm 17.4 \%$ within that of Camaret. Within Rade de Brest and Camaret, thalli exhibited branched forms (Figures 12-13).

\section{Environmental setting of the maerl beds}

Within the maerl beds of the Brittany coast mud content varied between 0 and $46.6 \%$ (Table 2). The highest mud content was found within the maerl beds of Rade de Brest (average mud content $=28.6 \pm 12.5 \%$ ) and Camaret (average mud content $=7.9 \pm 7.4 \%$ ), while other maerl beds developed on sediment with less than $2 \%$ of mud. The maerl beds of the Brittany coast were found between 0.7 and $25.9 \mathrm{~m}$ deep. The shallowest maerl beds developed within the Rade de Brest, between 0.7 and 6.8 m, while the deepest developed at Paimpol, between 10.8 and 25.9 m (Table 2).

The Brittany maerl beds were found in areas characterized by an annual mean current velocity varying between 0.02 and $0.73 \mathrm{~m} . \mathrm{s}^{-1}$ (Table 2). The lowest values were found at Trévignon (T2) and the highest at Paimpol (P1), where the maximum reached $1.71 \mathrm{~m} . \mathrm{s}^{-1}$. On the other hand, the annual mean wave agitation was lowest at Paimpol $\left(P 3=0.19 \pm 0.15 \mathrm{~m} \cdot \mathrm{s}^{-1}\right)$ and highest at Belle-lle $\left(B=0.62 \pm 0.49 \mathrm{~m} . \mathrm{s}^{-1}\right)$, where the maximum was 3.56 m.s. ${ }^{-1}$.

The maerl beds of the Brittany coast were found in areas characterized by annual mean water temperatures varying between 12.2 and $13.6^{\circ} \mathrm{C}$, calculated for Rade de Brest and Belle-lle, respectively, while the lowest winter value was $3.9^{\circ} \mathrm{C}$, calculated for Rade de Brest (Table 3). Annual mean salinity was highest at Paimpol (35.3) and lowest at Rade de Brest (31.9) which showed the lowest annual value (24.5) (Table 3). Annual mean suspended particulate matter (SPM) concentration varied between 0.5 and $2.2 \mathrm{mg} \cdot \mathrm{L}^{-1}$, while annual mean nitrate concentration varied 
between 3.3 and $41.0 \mu \mathrm{M}$ (Table 3). Rade de Brest showed the highest nitrate concentrations which could reach $148.2 \mu \mathrm{M}$ (Table 3). Annual mean oxygen saturation, varying between 92 and $100 \%$, appeared elevated for all the maerl beds (Table 3). The lowest oxygen saturation was calculated for Trévignon, where the summer value fell to $59 \%$.

\section{Relationships between maerl bed structure and environmental factors}

The BIOENV procedure indicated that the variations in the percent cover of thalli can best be explained by a combination of three environmental variables (correlation $=0.76)$. These corresponded to annual mean salinity, annual mean nitrate concentration and annual mean current velocity, showing individually a relatively high correlation with the percent cover of maerl thalli (correlation $=0.70$, 0.64 and 0.62 , respectively) compared to other environmental variables (correlation < 0.30). The NMDS ordinations based on the percent cover of maerl thalli and the best subset of explanatory environmental variables (annual mean salinity, annual mean nitrate concentration and annual mean current velocity), showed a relatively similar arrangement of the subareas along a horizontal axis (especially for B, P1 and P2) tending to respect their geographic distribution along the Brittany coast (Figures 1415). However, the subareas were separated into four distinct clusters in the NMDS ordination based on the percent cover of maerl thalli (Figure 14), while only the subareas corresponding to the maerl bed of Paimpol (P1, P2 and P3) were distinctly separated from the others in the NMDS ordination based on the best subset of explanatory environmental variables (Figure 15). The significance of these relationships was revealed by linear relationships between the percent cover of maerl 
thalli and annual mean salinity (log (percent cover) $=-0.26 \times$ annual mean salinity + $\left.10.84, n=10, R^{2}=0.81, p<0.01\right)$, annual mean nitrate concentration (log (percent cover) $=0.06 \times$ annual mean nitrate concentration $+1.47, n=10, R^{2}=0.78, p<$ 0.01 ), and annual mean current velocity (log (percent cover) $=-0.46 \times$ annual mean current velocity $+1.97, n=10, R^{2}=0.81, p<0.01$ ) (Figures 18-20). Spatial variations in annual mean salinity and annual mean nitrate concentration appeared to be negatively correlated (Spearman correlation $=-0.84, p<0.01)$. Annual mean current velocity also showed some degree of correlation with annual mean salinity (Spearman correlation $=0.61, p<0.01)$ and annual mean nitrate concentration (Spearman correlation $=-0.68, p<0.01)$. For the maerl beds of Belle-lle, Trévignon, Glénan, Molène and Paimpol, there was no significant relationship between the percent cover of maerl thalli and the proportion of living thalli $($ Spearman correlation $=$ $0.13, p=0.68)$.

As revealed by the BIOENV procedure, the variations in the proportion of living thalli can best be explained by the combination of depth and mud content (correlation $=0.47)$. These two environmental variables showed individually higher correlations (correlation $=0.36$ and 0.23 for depth and mud content, respectively) with the proportion of living thalli than the others (correlation $<0.18$ ). The NMDS ordinations based on the proportion of living thalli and the best subset of explanatory environmental variables (depth and mud content) tended to separate the subareas of the shallow maerl bed of Rade de Brest ( $R 1-R 18$, depth $<6.8 \mathrm{~m}$ ) from those of the the deeper maerl bed of Camaret $(\mathrm{C} 1-\mathrm{C} 10$, depth $>13.6 \mathrm{~m})$ (Figures 16-17). Similarly, the shallow subarea $(\mathrm{T} 2$, depth $=6.1 \mathrm{~m})$ of the maerl bed of Trévignon was separated from the deeper subarea $(\mathrm{T} 1$, depth $=14.1 \mathrm{~m})$ in the NMDS ordinations. For the maerl bed of Rade de Brest, where the range of mud content was the largest 
(2.7 - 46.6\%), NMDS ordinations separated also the subareas showing the lowest mud content (R1, R15 and R16, mud content $<10 \%$ ) from those showing the highest mud content (R4, R5, R6, R7 and R13, mud content $>40 \%$ ), independently from the depth. For the maerl bed of Camaret, NMDS ordinations based on the proportion of living thalli and the best subset of explanatory environmental variables also showed a relatively good match for the muddiest subareas $(\mathrm{C} 1, \mathrm{C} 6, \mathrm{C} 9$ and $\mathrm{C} 10$, mud content $>10 \%$ ), independently from the depth. Although mud content showed an overall correlation with depth (Spearman correlation $=-0.65, p<0.01$ ), these two environmental variables were not significantly correlated for a depth less than $10 \mathrm{~m}$ (Spearman correlation $=-0.15, p=0.52)$. For subareas deeper than $10 \mathrm{~m}$, proportion of living thalli was always lower than $30 \%$ while for subareas at less than $10 \mathrm{~m}$, it varied between 4 and $100 \%$ and showed a significant linear relationship with mud content $($ Figure 21, $\log ($ proportion of living thalli $)=-0.01 \times$ mud content $+2.03, n=$ $\left.20, R^{2}=0.53, p<0.01\right)$. In this case, the proportion of living thalli progressively decreased when mud content increased from 0 to $46.6 \%$. On the other hand, for mud content lower than $10 \%$, the proportion of living thalli showed a significant linear relationship with depth (Figure 22, log (proportion of living thalli) $=-0.05 \times$ depth + 2.11, $n=15, R^{2}=0.84, p<0.01$ ). Being strongly affected by human exploitation (see below), the proportions of living thalli within the maerl bed of Glénan (subareas G1 and G2) were not used to establish the linear relationships.

\section{Discussion}


Within the maerl beds of the Brittany coast, the percent cover of maerl thalli

422 appeared to be strongly related to spatial variations in both salinity and nitrate concentration. In fact, from the eastern part of Southern Brittany to the eastern part of Northern Brittany, the percent cover of maerl thalli decreased simultaneously with the increase in annual mean salinity and the decrease in annual mean nitrate concentration. Spatial variations in these two environmental variables are strongly driven by regular estuarine outputs from the Vilaine and Loire estuaries, situated in the eastern part of Southern Brittany, which generate a marked east-west gradient between riverine-influenced waters and oceanic-influenced waters (Dutertre et al., 2013). Simulations from the three-dimensional environmental models, as well as remote sensing observations, showed that the attenuated effects of plumes from both these rivers can also be detected as far as the Molène Archipelago during winter (December-February) floods. On the other hand, small rivers situated along the Brittany coast generate slightly decreasing gradients of estuarine conditions with distance from the shore. In Northern Brittany, the maerl bed of Paimpol was not affected by the estuarine outputs and was therefore subject to the lowest annual mean nitrate concentration and the highest annual mean salinity. The influence of estuarine outputs was clearly visible along the coastal fringe of Southern Brittany where the highest percent cover - more than $92 \%$ of the seabed covered - was found at Belle-lle, directly exposed to releases from the Loire and Vilaine Rivers, and at Trévignon, situated near the mouths of small rivers of Concarneau Bay. In areas adjacent to these maerl beds, the influence of estuarine outputs on benthic ecosystems was confirmed by the presence of particular macrofaunal communities (Glémarec, 1969; Dutertre et al., 2013). Although these results demonstrate an influence of estuarine outputs on the percent cover of maerl thalli, the individual 
effect of riverine-influenced factors is difficult to distinguish because they co-vary. The occurrence of European maerl beds near estuaries was formerly attributed to a drop in salinity measured in surface waters (Joubin, 1910). However, experimental studies appear necessary to understand how the spatial variations of the bottom salinity observed in this study influence the percent cover of maerl thalli. On the other hand, the data available about the nutrient fluxes in maerl communities found on Rade de Brest (Martin et al. 2007b) suggest that nitrate concentration could be the main riverine-influenced factor responsible for the variations in the percent cover of maerl thalli along the Brittany coast. In the same way, in the sublittoral zone of southwestern Hokkaido, a positive relationship was experimentally demonstrated between thallus growth of the coralline alga Lithophyllum yessoense and nitrate concentration ranging from 0 to $10 \mu \mathrm{M}$ (Ichiki et al., 2000) while, in the present study, annual mean nitrate concentration ranged from 3.32 to $8.16 \mu \mathrm{M}$. Taking into account the gradual increase in the amount of nitrates released by rivers since the 1970's, especially in relation to farming activities, their potential effect on maerl bed structure should be considered for conservation and management purposes. Another potential influence of estuarine outputs on the growth and reproduction of coralline algae constituting maerl beds could be variations in calcium concentration (Martin et al., 2006; 2007a). In fact, available data suggest that calcium carbonates accumulated in the Loire River are dissolved at the level of the estuary (Grosbois et al., 2001), involving a massive release of dissolved calcium which is probably spread by the river's plume. 
The Brittany maerl beds are found in seabed areas where the current velocity

471 showed an annual mean varying from 0.02 to $0.73 \mathrm{~m}^{-1} \mathrm{~s}^{-1}$, and a maximum reaching $1.71 \mathrm{~m} \cdot \mathrm{s}^{-1}$. In these areas, the percent cover of maerl thalli appeared related to the annual mean current velocity. The lowest percent cover - less than $59 \%$ of the seabed covered - was found within the Paimpol maerl bed, where the annual mean current velocity is higher than $0.50 \mathrm{~m} \cdot \mathrm{s}^{-1}$ whereas, within the other maerl beds, where the annual mean current velocity is lower than $0.30 \mathrm{~m} . \mathrm{s}^{-1}$, the percent cover of maerl thalli was higher than $66 \%$. Moreover, within the Paimpol maerl bed, the percent cover of maerl thalli was higher in the more sheltered subareas (P2 and P3). The strong relationship established between bottom current velocity and the percent cover of maerl thalli is probably due to their transport by water current as demonstrated in tropical reefs, where Scoffin et al. (1985) showed that individual branched thalli moved when the tidal current velocity reached $0.30-0.40 \mathrm{~m} \cdot \mathrm{s}^{-1}$. The dispersion of thalli occurring above this threshold of hydrodynamics is consistent with the lowest densities of maerl found within the maerl bed of Paimpol. Thus, the dominance of abraded sub-spheroidal thalli with warty protuberances in this maerl bed (Figures 9-11), as well as their presence in the maerl bed of Molène (Figures 78), can be associated with abrasion generated by the movements of thalli during their transport (Marrack, 1999).

Variations in both the percent cover and morphology of thalli can affect the associated biodiversity of maerl beds (Steller et al., 2003; Sciberras et al., 2009; Meihoub Berlandi et al., 2012). For example, when thalli are sparse or non-branched, maerl beds exhibit a less heterogeneous structure and contain less interstitial fauna. However, variations in thallus morphology due to the diversity of coralline algal species should also be considered. Although P. calcareum and L. corallioides are not 
characterized by sub-spheroidal thalli and have been reported to be dominant in Brittany maerl beds (Grall \& Hall-Spencer, 2003), this dominance must be confirmed by genetic studies.

\section{Environmental factors affecting the proportion of living thalli}

The proportion of living thalli in the maerl beds of the Brittany coast appeared significantly linked to depth and mud content. The relationship with depth was clearly highlighted by the fact that the proportion of living thalli was always lower than $30 \%$ in areas deeper than $10 \mathrm{~m}$, while the highest proportions of living thalli were only found at less than $10 \mathrm{~m}$. On the other hand, at less than $10 \mathrm{~m}$, the proportion of living thalli was also affected by the amount of mud contained in the sediment. For this depth range, the proportion of living thalli, which varied between 84 and $100 \%$ when sediment contained less than $10 \%$ of mud, decreased simultaneously with the increase in mud content. The effect of these two environmental variables on the proportion of living thalli can be related to the diminution of light intensity, even though the irradiance requirements of maerl species are not known and they are generally considered as low-light adapted organisms (Birkett et al., 1998; Wilson et al., 2004; Teichert et al., 2012). The proportion of penetrating light is known to decrease with depth, while silt deposition on thalli involves a smothering effect, limiting their access to light and/or gaseous exchange (Steller \& Foster, 1995; HallSpencer, 1998; Hall-Spencer \& Moore, 2000; Riul et al., 2008). For example, the burial of thalli resulting from the re-suspension of sediment by scallop dredging is known to involve a reduction in living thalli of more than $70 \%$, with no sign of recovery after four years (Wilson et al., 2004). Thus, the disappearance between 
1969 and 2009 of the maerl bed situated at the south of Quiberon Bay, where residual macrofaunal communities characterizing maerl habitat still subsist (Dutertre et al., 2013), probably results from the silting of thalli due to increased shellfish dredging activities and oyster farming. Although turbidity can also affect the penetration depth of light, the simulations of three-dimensional environmental models and remote sensing observations revealed that the concentration of suspended particle matter was relatively low (annual mean SPM concentration $<2.2 \mathrm{mg} \cdot \mathrm{L}^{-1}$ ) above the maerl beds. While Lemoine (1910) reported between 50 and $100 \%$ of living thalli within the maerl bed of Glénan, the lower proportions of living thalli $(<20$ $\%)$ observed now probably result from the huge exploitation which occurred during the second part of the twentieth century (Grall \& Hall-Spencer, 2003; Hall-Spencer et al., 2008). Indeed, the wash of extracted maerl involves a release of fine particles which deposit on the sea bottom and kill living maerl. The dominance of small poorlybranched thalli observed within the maerl bed of Glénan (Figures 5-6) can be also associated to fragmentation by dredging and extraction (Hall-Spencer \& Moore, 2000).

$$
\text { Implications for the conservation and management of the maerl beds }
$$

The large spatial scale ecological approach implemented in this study provides findings having significant implications for the conservation and management of the ecologically interesting benthic habitats constituted by maerl beds. This approach enables the detection of the influence of some important factors, such as estuarine outputs, occurring at a wider spatial scale than that considered by local surveys generally performed in marine benthic ecology. Moreover, while local environmental 
conditions can lead to misinterpretations of benthic habitat characteristics at a small spatial scale (Ellis \& Schneider, 2008), site-to-site comparisons of the physical environment reduce site-related artefacts and enable a more realistic environmental setting of the maerl beds, including anthropogenic effects. More specifically, the quantitative results provided by this study enable the determination of environmental thresholds explaining the structural heterogeneity of maerl beds on which depends the biological diversity associated with this habitat (Steller et al., 2003; Sciberras et al., 2009; Meihoub Berlandi et al., 2012). The non-explained part of this structural heterogeneity can be therefore related to non-tested factors, including the impacts of human activities such as fishing, aquaculture or extraction, which are often difficult to quantify and distinguish from naturally-induced effects (Barbera et al., 2003). Within the framework of the implementation of conservation and management strategies of the maerl beds, and of the improvement of benthic habitat modeling, such quantifications are usable to understand better how the structure of maerl beds differs between them and how it may change with time (Barbera et al., 2003; Méléder et al., 2010).

The output from mathematical models may not fully represent the complex functioning of the coastal environment and their use is dependent on the spatial and time resolutions. Nevertheless, the significant relationships established between maerl bed structure and physical factors suggest that, after validations by field data, three-dimensional environmental models can be useful tools to support ecosystem management in particular by enabling the generation of summary statistics to quantify the effect of highly variable hydrological factors. In fact, numerical models can generate continuous variations in a large variety of environmental factors, even in marine areas where monitoring is not easy such as the sea bottom. Considering 
the diversity of the environmental factors used and the reliability of the 3D models at a large spatial scale (Ménesguen et al., 2007), our results provide a good estimation of the part of the structural heterogeneity of the maerl beds which can be explained by the abiotic factors tested. However, as maerl beds are persistent in time and constituted by long-lived maerl thalli (Barbera et al., 2003), their structural heterogeneity can also result from environmental changes (e.g. climate warming and nutrient enrichment) and/or exceptional climatic events (e.g. storms) which occurred over past years but cannot be correctly estimated with the models used in this study due to the lack of consistent and reliable field validations for years prior to 2009.

Another important point to take into account when determining the environmental influence on maerl beds is the taxonomic diversity of the maerl thalli. For example, as it is difficult to distinguish dominant "maerl" species clearly without histological observations or genetic analyses, maerl beds may be constituted by a mix of different coralline algal species. Thus, although the ecological requirements of each "maerl" species are still not clearly known, the relative proportion of these species within a maerl bed could influence variations in the environmental setting of maerl beds.

\section{Acknowledgements}

This work was jointly funded by IFREMER and the French Agency for Protected Marine Areas (AAMP), which have also funded the French program REBENT alongside Region Bretagne and the European Regional Development Fund (FEDER). The authors wish to thank Philippe Cugier, Alain Ménesguen, and Fabrice Lecornu, coordinator of the PREVIMER project, for the use of the 3D environmental 
595

596

597

598

599

600

601

602

603

604

605

606

607

608

609

610

611

612

613

614

615

616

617

618

models. We also thank Xavier Caisey and Jean-Dominique Gaffet for their technical assistance, as well as anonymous reviewers for their valuable comments on the manuscript.

\section{References}

Adey, W.H. \& McKibbin, D.L. (1970). Studies on the maerl species Phymatolithon calcareum (Pallas) nov. comb. and Lithothamnion corallioides Crouan in the Ria de Vigo. Botanica Marina, 13: 100-106.

Ardhuin, F., Accensi, M., Roland, A., Girard, F., Filipot, J.-F., Leckler, F. \& Le Roux, J.-F. (2014). Numerical wave modeling in PREVIMER: multi-scale and multiparameter demonstrations. Mercator Ocean - Quarterly Newsletter, 49: 39-43.

Barbera, C., Bordehore, C., Borg, J.A., Glémarec, M., Grall, J., Hall-Spencer, J.M., De la Huz, C., Lanfranco, E., Lastra, M. \& Moore, P.G. (2003). Conservation and management of northeast Atlantic and Mediterranean maerl beds. Aquatic Conservation:Marine and Freshwater Ecosystems, 13: S65-S76.

Birkett, D.A., Maggs, C.A. \& Dring, M.J. (1998). Maerl (volume V). An overview of dynamic and sensitivity characteristics for conservation management of marine SACs. Scottish Association for Marine Science (UK Marine SACs Project).

Bosence, D.W.J. (1983). The occurrence and ecology of recent rhodoliths - a review. In T.M. Peryt (Editor), Coated Grains. Springer-Verlag, Berlin, 225-242.

Clarke, K.R. \& Ainsworth, M. (1993). A method of linking multivariate community structure to environmental variables. Marine Ecology Progress Series, 92: 205219. 
Cugier, P. \& Le Hir, P. (2002). Development of a 3D hydrodynamic model for coastal ecosystem modelling. Application to the plume of the Seine River (France). Estuarine, Coastal and Shelf Science, 55: 673-695.

De Grave, S., Fazakerley, H., Kelly, L., Guiry, M.D., Ryan, M. \& Walshe, J. (2000). A study of selected maerl beds in Irish waters and their potential for sustainable extraction. Marine Resource Series, No. 10. Marine Institute, Dublin.

Dumas, F., Pineau-Guillou, L., Lecornu, F., Le Roux, J.-F. \& Le Squère, B. (2014). General introduction: previmer, a french pre-operational coastal ocean forecasting capability. Mercator Ocean - Quarterly Newsletter, 49: 3-8.

Dutertre, M., Hamon, D., Chevalier, C. \& Ehrhold, A. (2013). The use of the relationships between environmental factors and benthic macrofaunal distribution in the establishment of a baseline for coastal management. ICES Journal of Marine Science, 70: 294-308.

Ellis, J.T. \& Schneider, D.C. (2008). Spatial and temporal scaling in benthic ecology. Journal of Experimental Marine Biology and Ecology, 366: 92-98.

Foster, M.S. (2001). Rhodoliths: between rocks and soft places. Journal of Phycology, 37: 659-667.

Freiwald, A. \& Henrich, R. (1994). Reefal coralline algal build-ups within the Arctic Circle: morphology and sedimentary dynamics under extreme environmental seasonality. Sedimentology, 41: 963-984.

Glémarec, M. (1969). Les peuplements benthiques du plateau continental nordGascogne. PhD thesis, Université de Paris.

Gogina, M. \& Zettler, M.L. (2010). Diversity and distribution of benthic macrofauna in the Baltic Sea. Data inventory and its use for species distribution modelling and prediction. Journal of Sea Research, 64: 313-321. 
644

645

646

647

648

649

650

651

652

653

654

655

656

657

658

659

660

661

662

663

664

665

666

667

668

Grall, J. \& Hall-Spencer, J.M. (2003). Problems facing maerl conservation in Brittany. Aquatic Conservation: Marine and Freshwater Ecosystems, 13: S55-S64.

Grall, J., Le Loc'h, F., Guyonnet, B. \& Riera, P. (2006). Community structure and food web based on stable isotopes $(\delta 15 \mathrm{~N}$ and $\delta 13 \mathrm{C})$ analyses of a North Eastern Atlantic maerl bed. Journal of Experimental Marine Biology and Ecology, 338: 1-15.

Grosbois, C., Négrel, P., Grimaud, D. \& Fouillac, C. (2001). An overview of dissolved and suspended matter fluxes in the Loire River basin: natural and anthropogenic inputs. Aquatic Geochemistry, 7: 81-105.

Hall-Spencer, J.M. (1998). Conservation issues concerning the molluscan fauna of maerl beds. Journal of Conchology Special Publication, 2: 271-286.

Hall-Spencer, J.M., Grall, J., Moore, P.G. \& Atkinson, R.J.A. (2003). Bivalve fishing and maerl-bed conservation in France and the UK - retrospect and prospect. Aquatic Conservation: Marine and Freshwater Ecosystems, 13: S33-S41.

Hall-Spencer, J.M., Kelly, J. \& Maggs, C.A. (2008). Assessment of maerl beds in the OSPAR area and the development of a monitoring program. Department of the Environment, Heritage \& Local Government (DEHLG), Ireland.

Hall-Spencer, J.M. \& Moore, P.G. (2000). Scallop dredging has profound, long-term impacts on maerl habitats. ICES Journal of Marine Science, 57: 1407-1415.

Ichiki, S., Mizuta, H. \& Yamamoto, H. (2000). Effects of irradiance, water temperature and nutrients on the growth of sporelings of the crustose coralline alga Lithophyllum yessoense Foslie (Corallinales, Rhodophyceae). Phycological Research, 48: 115-120.

Jacquotte, R. (1962). Étude des fonds de maërl de Méditerranée. Recueil des Travaux de la station marine d'Endoume, 26: 141-235. 
669

670

671

672

673

674

675

676

677

678

679

680

681

682

683

684

685

686

687

688

689

690

691

Joubin, L. (1910). Recherches sur la distribution océanographique des végétaux marins dans la région de Roscoff. Annales de l'Institut Océanographique de Monaco, 1: 1-17.

Lazure, P. \& Dumas, F. (2008). An external-internal mode coupling for a 3D hydrodynamical model for applications at regional scale (MARS). Advances in Water Resources, 31: 233-250.

Lemoine, P. (1910). Répartition et mode de vie du maërl (Lithothamnium calcareum) aux environs de Concarneau (Finistère). Annales de l'Institut océanographique, Paris, 1: 1-29.

Marrack, E.C. (1999). The relationship between water motion and living rhodolith beds in the southwestern Gulf of California, Mexico. Palaios, 14: 159-171.

Martin, S., Castets, M.D. \& Clavier, J. (2006). Primary production, respiration and calcification of the temperate free-living coralline alga Lithothamnion corallioides. Aquatic Botany, 85: 121-128.

Martin, S., Clavier, J., Chauvaud, L. \& Thouzeau, G. (2007a). Community metabolism in temperate maerl beds. I. Carbon and carbonate fluxes. Marine Ecology Progress Series, 335: 19-29.

Martin, S., Clavier, J., Chauvaud, L. \& Thouzeau, G. (2007b). Community metabolism in temperate maerl beds. II. Nutrient fluxes. Marine Ecology Progress Series, 335: 31-41.

Meihoub Berlandi, R., Figueiredo, M.A.O. \& Paiva, P.C. (2012). Rhodolith morphology and the diversity of polychaetes off the Southeastern Brazilian Coast. Journal of Coastal Research, 28(1): 280-287. 
692

693

694

695

696

697

698

699

700

701

702

703

704

705

706

707

708

709

710

711

712

713

714

715

Méléder, V., Populus, J., Guillaumont, B., Perrot, T. \& Mouquet, P. (2010). Predictive modelling of seabed habitats: case study of subtidal kelp forests on the coast of Brittany, France. Marine Biology, 157: 1525-1541.

Ménesguen, A., Dussauze, M., Lecornu, F., Dumas, F. \& Thouvenin, B. (2014). Operational modelling of nutrients and phytoplancton in the bay of Biscay and English Channel. Mercator Ocean - Quarterly Newsletter, 49: 87-92.

Ménesguen, A., Cugier, P., Loyer, S., Vanhoutte-Brunier, A., Hoch, T., Guillaud, J.-F. \& Gohin, F. (2007). Two- or three-layered box models versus fine 3D models for coastal ecological modelling? A comparative study in the English Channel (Western Europe). Journal of Marine Systems, 64: 47-65.

Peña, V. \& Bárbara, I. (2008). Maërl community in the north-western Iberian Peninsula: a review of floristic studies and long-term changes. Aquatic Conservation:Marine and Freshwater Ecosystems, 18: 339-366.

Peña, V. \& Bárbara, I. (2010). Seasonal patterns in the maërl community of shallow European Atlantic beds and their use as a baseline for monitoring studies. European Journal of Phycology, 45(3): 327-342.

Przeslawski, R., Currie, D.R., Sorokin, S.J., Ward, T.M., Althaus, F. \& Williams, A. (2011). Utility of a spatial habitat classification system as a surrogate of marine benthic community structure for the Australian margin. ICES Journal of Marine Science, 68: 1954-1962.

Riul, P., Targino, C.H., Farias, J.N., Visscher, P.T. \& Horta, P.A. (2008). Decrease in Lithothamnion sp. (Rhodophyta) primary production due to the deposition of a thin sediment layer. Journal of the Marine Biological Association of the United Kingdom, 88: 17-19. 
Sciberras, M., Rizzo, M., Mifsud, J.R., Camilleri, K., Borg, J.A., Lanfranco, E. \& Schembri, P.J. (2009). Habitat structure and biological characteristics of a maerl bed off the northeastern coast of the Maltese Islands (central Mediterranean). Marine Biodiversity, 39: 251-264.

Scoffin, T.P., Stoddart, D.R., Tudhope, A.W. \& Woodroffe, C. (1985). Rhodoliths and coralliths of Muri Lagoon, Rarotonga, Cook Islands. Coral Reefs, 4: 71-80.

Steller, D.L., Foster, M.S. (1995). Environmental factors influencing distribution and morphology of rhodoliths in Bahía Concepción, B.C.S., Mexico. Journal of Experimental Marine Biology and Ecology, 194: 201-212.

Steller, D.L., Riosmena-Rodríguez, R., Foster, M.S. \& Roberts, C.A. (2003). Rhodolith bed diversity in the Gulf of California: the importance of rhodolith structure and consequences of anthropogenic disturbances. Aquatic Conservation: Marine and Freshwater Ecosystems, 13: S5-S20.

Teichert, S., Woelkerling, W., Rüggeberg, A., Wisshak, M., Piepenburg, D., Meyerhofer, M., Form, A., Büdenbender, J. \& Freiwald, A. (2012). Rhodolith beds (Corallinales, Rhodophyta) and their physical and biological environment at $80^{\circ} 31^{\prime} \mathrm{N}$ in Nordkappbukta (Nordaustlandet, Svalbard Archipelago, Norway). Phycologia, 51(4): 371-390.

Tolman, H.L. (2002). Distributed-memory concepts in the wave model WAVEWATCH III. Parallel Computing, 28: 35-52.

Warwick, R.M. \& Uncles, R.J. (1980). Distribution of benthic macrofauna associations in the Bristol Channel in relation to tidal stress. Marine Ecology Progress Series, 3: $97-103$. 
739 Wilson, S., Blake, C., Berges, J.A. \& Maggs, C.A. (2004). Environmental tolerances 740 of free-living coralline algae (maerl): implications for European maerl 741 conservation. Biological Conservation, 120: 283-293. 
743 Table 1. Subareas and associated number of sampling stations for the Brittany maerl

744 beds. For each maerl bed, the total area and the materials used for the determination

745 of maerl bed structure are indicated.

\begin{tabular}{|c|c|c|c|}
\hline Maerl bed & $\begin{array}{c}\text { Total area } \\
\left(\mathrm{km}^{2}\right)\end{array}$ & $\begin{array}{c}\text { Subareas } \\
\text { (number of sampling stations) }\end{array}$ & Materials \\
\hline Belle-lle & 16.8 & $\mathrm{~B}(12)$ & $\begin{array}{c}\text { Shipek grab samples } \\
\text { Underwater video recordings }\end{array}$ \\
\hline Trévignon & 23.0 & $\mathrm{~T} 1(2), \mathrm{T} 2(4)$ & $\begin{array}{l}\text { Shipek grab samples } \\
\text { Underwater video recordings }\end{array}$ \\
\hline Glénan & 5.2 & G1(5), G2(2) & $\begin{array}{l}\text { Shipek grab samples } \\
\text { Underwater video recordings }\end{array}$ \\
\hline Camaret & 1.9 & $\begin{array}{c}\mathrm{C} 1-\mathrm{C} 10 \\
\text { (1 sampling station / subarea) }\end{array}$ & Smith-McIntyre grab samples \\
\hline Rade de Brest & 10.7 & $\begin{array}{c}\mathrm{R} 1-\mathrm{R} 18 \\
\text { (1 sampling station / subarea) }\end{array}$ & Smith-Mclntyre grab samples \\
\hline Molène & 2.8 & $M 1(11), M 2(2)$ & $\begin{array}{l}\text { Shipek grab samples } \\
\text { Underwater video recordings }\end{array}$ \\
\hline Paimpol & 22.2 & $\mathrm{P} 1(5), \mathrm{P} 2(12), \mathrm{P} 3(5)$ & $\begin{array}{l}\text { Shipek grab samples } \\
\text { Underwater video recordings }\end{array}$ \\
\hline
\end{tabular}


Table 2. Morpho-sedimentary and hydrodynamic characteristics of the maerl beds of

749 the Brittany coast. Mud content was measured in grab samples, while current velocity 750 and wave agitation were generated near the bottom by three-dimensional numerical 751 models. For current velocity and wave agitation, annual mean (bold characters) and 752 annual maximum values are given, while annual minimum values are equal to 0 in all 753 cases.

\begin{tabular}{|c|c|c|c|c|}
\hline Maerl bed & $\begin{array}{c}\text { Mud content } \\
(\%)\end{array}$ & $\begin{array}{l}\text { Depth } \\
(\mathrm{m})\end{array}$ & $\begin{array}{l}\text { Current velocity } \\
\qquad\left(m \cdot s^{-1}\right)\end{array}$ & $\begin{array}{c}\text { Wave agitation } \\
\qquad\left(\mathrm{m} \cdot \mathrm{s}^{-1}\right)\end{array}$ \\
\hline \multirow[t]{2}{*}{ Belle-lle } & 0 & $10.0-17.9$ & 0.20 & 0.62 \\
\hline & & & $\max .=0.34$ & $\max .=3.56$ \\
\hline \multirow[t]{2}{*}{ Trévignon } & $1.0-2.0$ & $1.9-15.8$ & $0.02-0.06$ & $0.36-0.37$ \\
\hline & & & $\max .=0.18$ & $\max .=2.86$ \\
\hline \multirow[t]{2}{*}{ Glénan } & 0 & $4.8-19.5$ & $0.14-0.23$ & $0.35-0.39$ \\
\hline & & & $\max .=0.49$ & $\max .=3.10$ \\
\hline \multirow[t]{2}{*}{ Camaret } & $0.4-21.2$ & $13.6-20.8$ & $0.07-0.31$ & $0.14-0.36$ \\
\hline & & & $\max .=0.44$ & $\max .=5.50$ \\
\hline \multirow[t]{2}{*}{ Rade de Brest } & $2.7-46.6$ & $0.7-6.8$ & $0.08-0.26$ & $0.01-0.09$ \\
\hline & & & $\max .=0.43$ & $\max .=3.57$ \\
\hline \multirow[t]{2}{*}{ Molène } & 0 & $7.0-12.6$ & 0.26 & $0.22-0.39$ \\
\hline & & & $\max .=1.52$ & $\max .=2.57$ \\
\hline \multirow[t]{2}{*}{ Paimpol } & 0 & $10.8-25.9$ & $0.59-0.73$ & $0.19-0.27$ \\
\hline & & & $\max .=1.71$ & $\max .=1.87$ \\
\hline
\end{tabular}

754 
Table 3. Physico-chemical properties of the water column generated near the bottom

758 each environmental variable, annual mean value (bold characters) and annual range

759 of variations are given.

\begin{tabular}{|c|c|c|c|c|c|}
\hline Maerl bed & $\begin{array}{c}\text { Temperature } \\
\left({ }^{\circ} \mathrm{C}\right)\end{array}$ & Salinity & $\begin{array}{c}\text { SPM } \\
\text { concentration } \\
\left(\mathrm{mg}^{-1} \mathrm{~L}^{-1}\right)\end{array}$ & $\begin{array}{c}\text { Nitrate } \\
\text { concentration } \\
(\mu \mathrm{M})\end{array}$ & $\begin{array}{c}\text { Oxygen } \\
\text { saturation } \\
(\%)\end{array}$ \\
\hline \multirow[t]{3}{*}{ Belle-Ile } & 13.6 & 34.2 & 2.2 & 7.3 & 95 \\
\hline & $\min .=7.7$ & $\min .=32.8$ & $\min .=0.6$ & $\min .=2.2$ & $\min .=81$ \\
\hline & $\max .=18.5$ & $\max .=34.8$ & $\max .=6.9$ & $\max .=19.2$ & $\max .=100$ \\
\hline \multirow[t]{3}{*}{ Trévignon } & $12.8-12.9$ & $34.3-34.4$ & $1.6-1.7$ & $7.8-8.1$ & $90-92$ \\
\hline & $\min .=7.4$ & $\min .=32.5$ & $\min .=0.5$ & $\min .=3.0$ & $\min .=59$ \\
\hline & $\max .=17.9$ & $\max .=34.9$ & $\max .=5.2$ & $\max .=23.3$ & $\max .=100$ \\
\hline \multirow[t]{3}{*}{ Glénan } & 13.3 & 34.5 & $1.7-1.8$ & $6.7-6.8$ & 94 \\
\hline & $\min .=7.7$ & $\min .=33.0$ & $\min .=0.6$ & $\min .=2.9$ & $\min .=74$ \\
\hline & $\max .=17.6$ & $\max .=35.1$ & $\max .=5.4$ & $\max .=19.5$ & $\max .=100$ \\
\hline \multirow[t]{3}{*}{ Camaret } & 13.2 & 35.1 & 0.5 & $6.5-7.3$ & $94-95$ \\
\hline & $\min .=9.1$ & $\min .=34.4$ & $\min .=0.4$ & $\min .=0.5$ & $\min .=69$ \\
\hline & $\max .=16.5$ & $\max .=35.4$ & $\max .=0.8$ & $\max .=21.2$ & $\max .=100$ \\
\hline \multirow[t]{3}{*}{ Rade de Brest } & $12.2-13.1$ & $31.9-34.5$ & $0.7-1.6$ & $12.0-41.0$ & $98-100$ \\
\hline & $\min .=3.9$ & $\min .=24.5$ & $\min .=0.5$ & $\min .=0.1$ & $\min .=78$ \\
\hline & $\max .=17.9$ & $\max .=35.3$ & $\max .=6.5$ & $\max .=148.2$ & $\max .=100$ \\
\hline \multirow[t]{3}{*}{ Molène } & $13.2-13.3$ & 34.8 & 1.2 & $5.5-6.1$ & 98 \\
\hline & $\min .=8.7$ & $\min .=34.1$ & $\min .=0.5$ & $\min .=3.0$ & $\min .=91$ \\
\hline & $\max .=17.4$ & $\max .=35.2$ & $\max .=3.1$ & $\max .=18.0$ & $\max .=100$ \\
\hline \multirow[t]{3}{*}{ Paimpol } & $13.1-13.2$ & 35.3 & $0.9-1.2$ & 3.3 & 99 \\
\hline & $\min .=7.8$ & $\min .=35.2$ & $\min .=0.5$ & $\min .=0.2$ & $\min .=97$ \\
\hline & $\max .=17.9$ & $\max .=35.4$ & $\max .=2.4$ & $\max .=8.1$ & $\max .=100$ \\
\hline
\end{tabular}




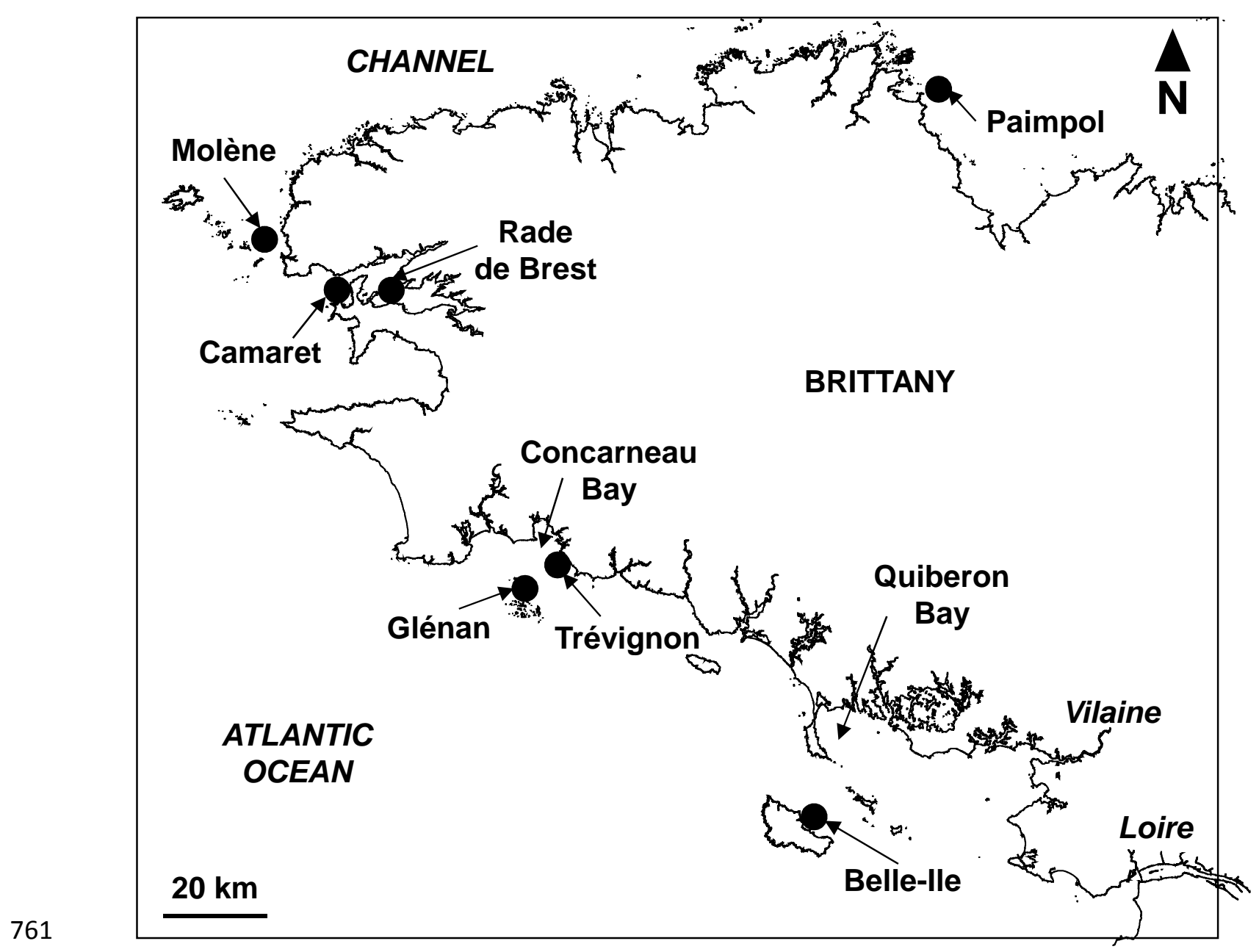

762 Figure 1. Location of the seven Brittany maerl beds studied by IFREMER (Paimpol,

763 Molène, Glénan, Trévignon and Belle-lle) and IUEM (Rade de Brest and Camaret). 

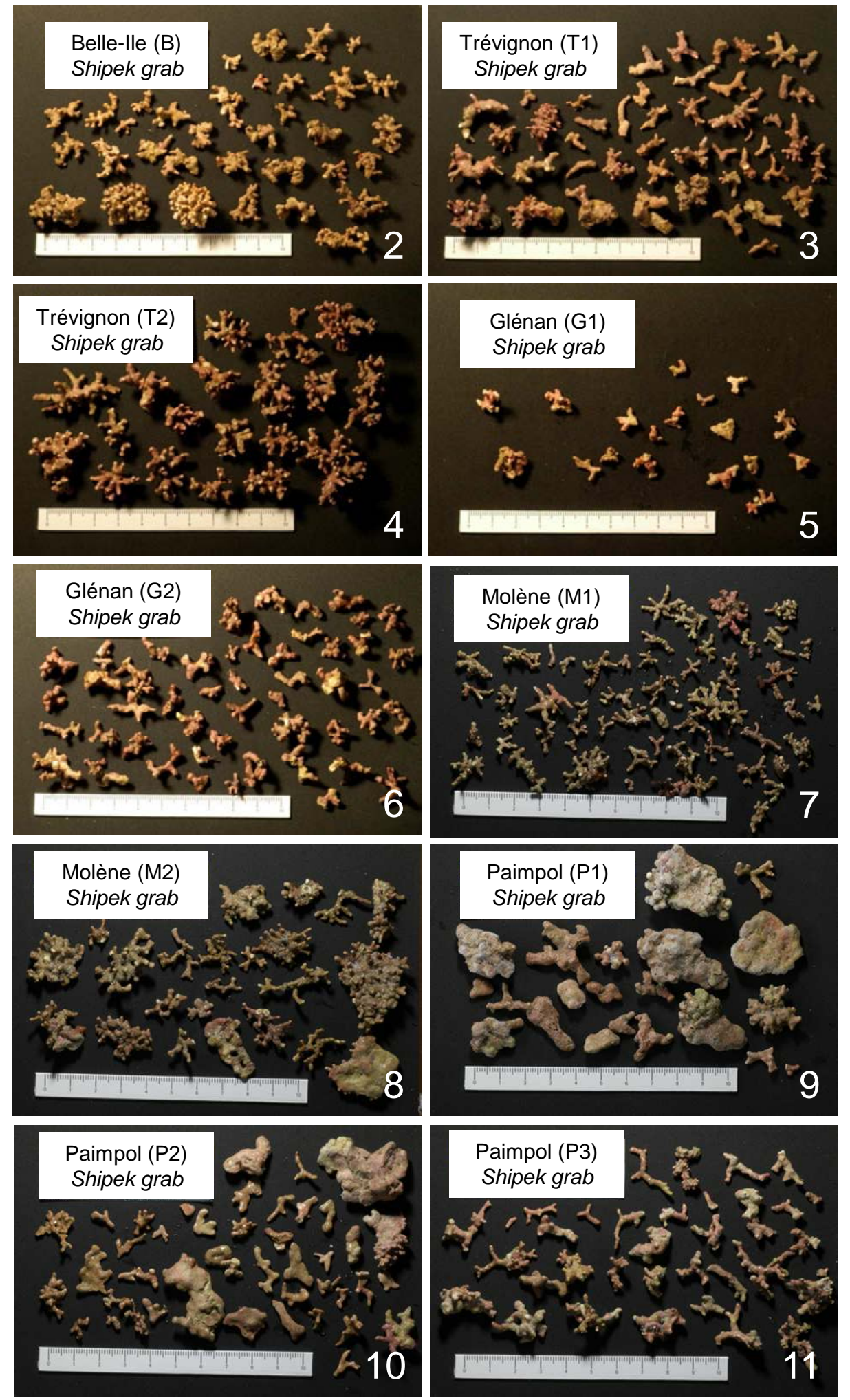

766 Figures 2-11. Examples of thallus morphology found within the subareas of the maerl

767 beds of Belle-lle (B), Trévignon (T1 and T2), Glénan (G1 and G2), Molène (M1 and M2) and Paimpol (P1, P2 and P3). 

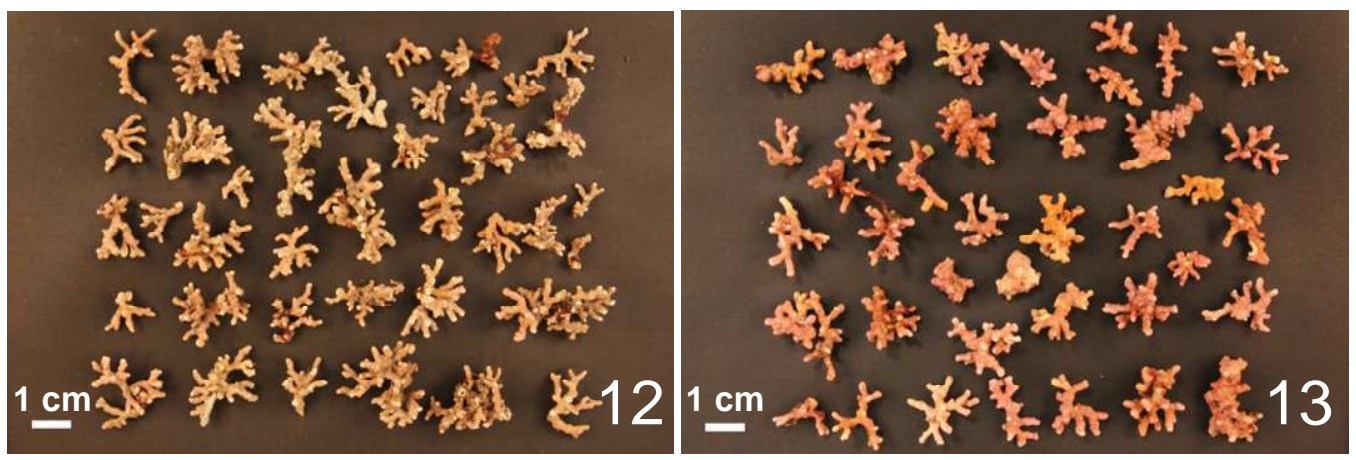

769

770 Figures 12-13. Examples of thallus morphology found within the Smith-Mclntyre grab

771 samples collected within the maerl beds of Rade de Brest (subarea R15, Figure 12)

772 and Camaret (subarea C2, Figure 13).

773 


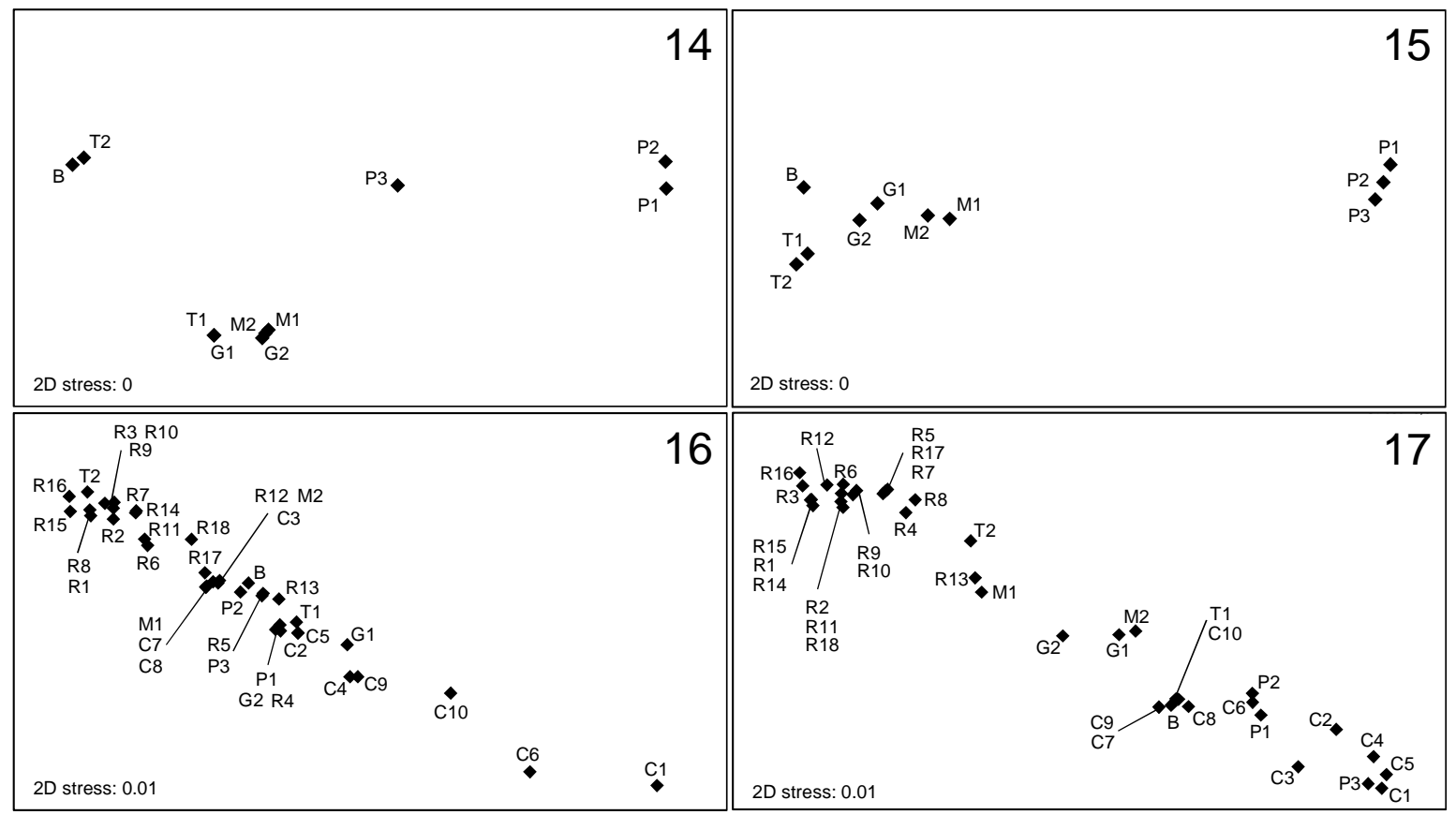

775 Figures 14-17. Nonmetric multidimensional scaling (NMDS) ordinations of the 776 subareas of the Brittany maerl beds (Belle-lle (B), Trévignon (T1 - T2), Glénan (G1 777 G2), Camaret (C1 - C10), Rade de Brest (R1 - R18), Molène (M1 - M2), and Paimpol 778 (P1 - P3)). NMDS ordinations are based on the percent cover of maerl thalli (Figure 779 14) and the associated best subset of explanatory environmental variables (annual 780 means of salinity, nitrate concentration and current velocity, Figure 15), and on the 781 proportion of living thalli (Figure 16) and the associated best subset of explanatory 782 environmental variables (depth and mud content, Figure 17). 

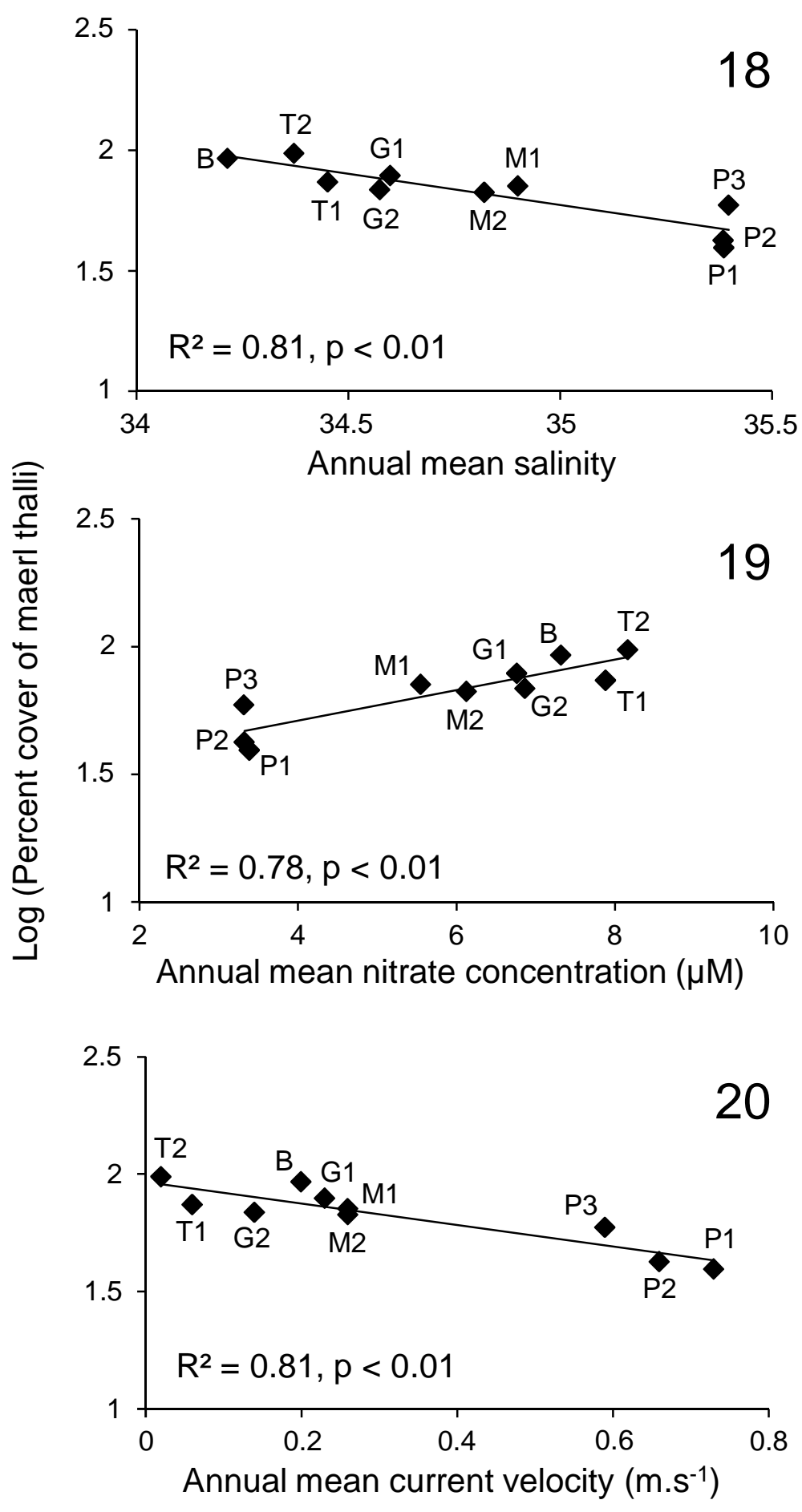

785 Figures 18-20. Significant linear relationships $(p<0.01)$ between the percent cover of 786 maerl thalli observed in the subareas of the Brittany maerl beds (Belle-lle (B), 787 Trévignon (T1 - T2), Glénan (G1 - G2), Molène (M1 - M2), and Paimpol (P1 - P3)) 788 and environmental variables (annual means of salinity, nitrate concentration and current velocity). 


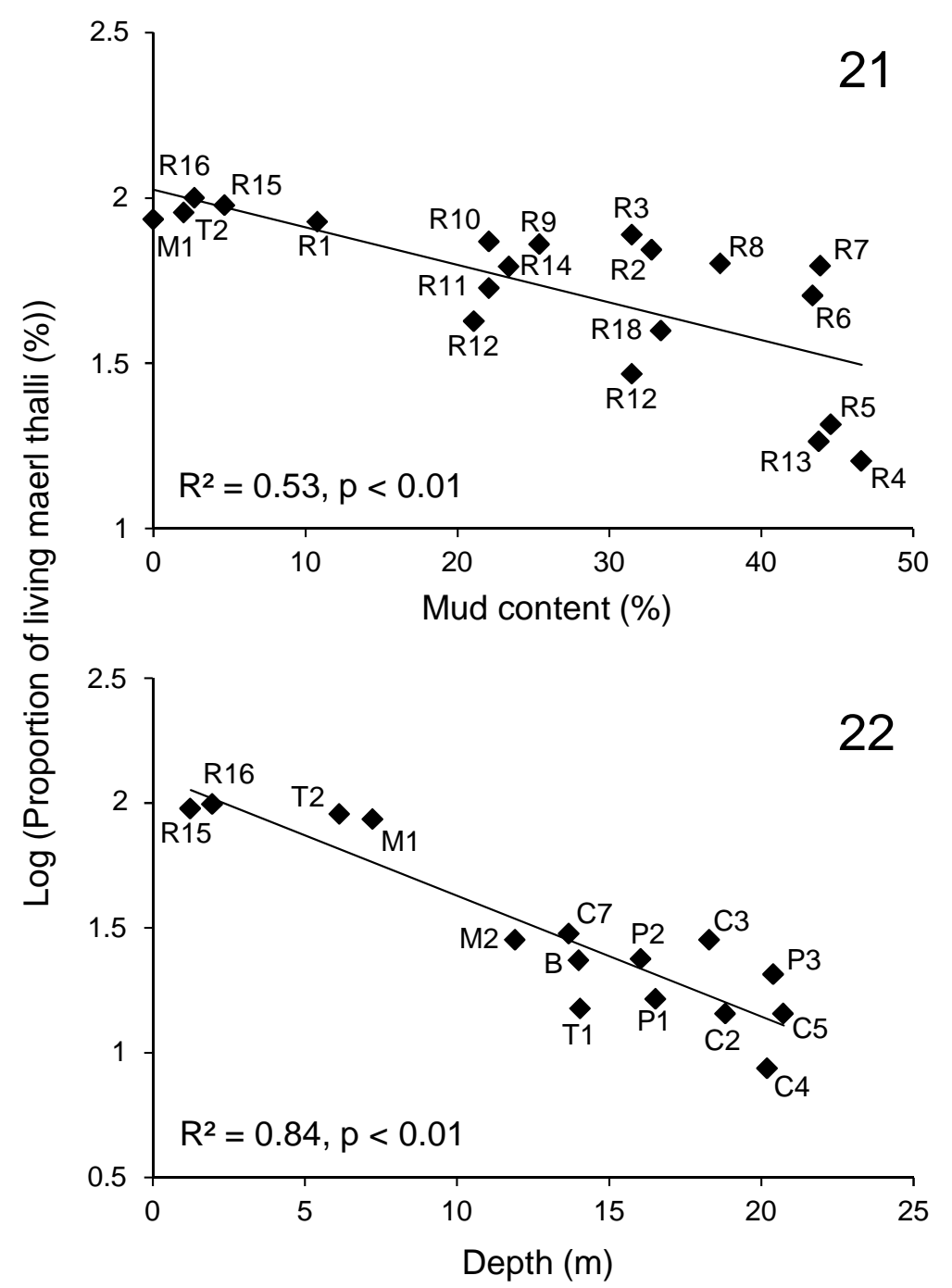

790

Figures 21-22. Significant linear relationships $(p<0.01)$ between the proportions of 792 living thalli observed in the subareas of the Brittany maerl beds (Belle-lle (B), 793 Trévignon (T1 - T2), Camaret (C1 - C10), Rade de Brest (R1 - R18), Molène (M1 794 M2), and Paimpol (P1 - P3)) and environmental variables (depth and mud content). 795 The relationship with mud content was established for subareas situated at less than $79610 \mathrm{~m}$ of depth (Figure 21), while the relationship with depth was established for 797 subareas showing less than $10 \%$ of mud (Figure 22). 